\title{
Dysfunction of the Law Number 1 of 1970 to Tackle Criminal Acts of Occupational Safety and Health (OSH)
}

\author{
Parningotan Malau ${ }^{1}$, Alvi Syahrin ${ }^{2}$ \\ Universitas Sumatera Utara, Medan, Indonesia ${ }^{1,2}$ \\ \{pmalau0707@gmail.com²,alviprodr@gmail.com²
}

\begin{abstract}
Act 1 year 1970 on Occupational Safety (UUKK) is a legal umbrella of Occupational Safety and Health (OSH) of Indonesia. UUKK uses penal policy as a rational effort to tackle criminal protection of OSH worker/labor in the workplace. However, the high industrial accident that occurred every year that caused many workers/laborers suffered defects/death, and the absence of industrial accident cases that use UUKK as the basis for prosecution/criminal radiomen indicates that UUKK dysfunction. There is a contradiction with the Constitution of the Republic of Indonesia (UUDNRI) of 1945 that explicitly provide a guarantee of OSH protection as a human rights worker in the workplace. The protection of OSH workers is the derivation of the values of Pancasila which is the guidance of the state and every community association, including in the industry working relationship between the entrepreneurs/corporations and workers/workers. The objectives of the UUKK penal policy are in line with the country's purpose, which is to provide OSH protection for the welfare of workers/laborers, as mentioned on The Fourth Opening of UUDNRI in 1945. The problem raised, why UUKK dysfunction. Search the root of the problem using a normative juridical research method with the legislation approach. The results of the study concluded, UUKK dysfunction caused the poor policy of criminal formulation of UUKK so it does not allow to be enforced because it is recommended, renewal of the formulation policy of UUKK with attention to the social realities of society.
\end{abstract}

Keywords: UUKK, OSH protection worker/labor, Criminal policy formulation

\section{Introduction}

The development of science and technology along with human civilization, as well as the dangers they cause (Soehatman Ramli, 2010). Industrialization, although provides great benefits, but with various modes can be the cause of disaster (disaster), accident, and various diseases (GEMEENSCHAP) due to lack of/not managed (manage) well (Sutan Remy Sjadeini, 2007). The same issue occurs in industrial work environments. The Sources of hazards contained in or industrial work environment potentially become the real hazards to high potential hazards level) resulting in accident. The hazard and disease sources at any time can threaten OSH worker/labor protection (Suma'mur, 1981). The industrial accident brought the impact of huge and vast economic losses, especially to the workers/laborers (and their families) whose position was both economically, socially and psychology far weaker than the businessman/corporation (Asri Wijayanti, 2010). The corporation has brought a positive impact 
on the progress of various aspects of development, but in the midst of its existence also has a negative impact, namely performing various criminal acts, such as illegal abuse of economic power (Dwidja Priyatno and Kristian, 2017), such as a Criminal Protection Act of OSH workers/laborers in the workplace industry. Corporations are more profit oriented as much as possible without regard to social aspects. Corporate crime in protecting OSH workers/laborers in the workplace is explained by Steven Box's analysis. Steven Box comprehensively described that corporate crime motives are basically related to economic activities or the business world. Steven Box comprehensively described that corporate crime motives are basically related to economic activities or the business world. Corporate crime occurs due to a conflict or contradiction between variables relating to organizational goals on the one hand and the demands of the environment around the organization on the other, one of which is the demands of the needs of workers/laborers. Corporate crime occurs due to the conflict or contradiction between variables involving organizational goals on one side with demands around the needs of other organizations, one of which is the demand for workers/laborers. The obsession/enthusiasm of the organization (corporation) to achieve / increase profit growth (profit), mastery of market control which is characterized by individual characteristics namely anomy, unlimited ambition), shrewdness) and morality/immoral. All seen as situational demands and learnt in association with other corporation executives. The contradiction by Steven Box was a motif that changed or transformed into a corporate crime.

Joseph F. Sheley argued corporations who ignored OSH workers/laborers were the dimension patterns of corporate crimes developed as the national and international economic developments (Hanafi 1, 1997; Suparman Marzuki, 1994). The same opinion was stated by Niall F. Coburn, that one of the dimensions of corporate crime is related to OSH protection of workers/laborers. Submitted, corporate crimes usually initially where there are gaps in procedures. Individuals see weakness in the existing system and take advantage of an opportunity that is presented them (Niall F. Coburn, 2006). Joseph F. Sheley also argued, that corporate crimes are always in connection with economic activities through; defrauding stockholders, defrauding the public, defrauding the government, illegal intervention in the political process, endangering the public welfare (H. Setiyono, 2009). Hanafi defines its endangering employees as a dimension of corporate crime that does not treat for OSH (Hanafi 2, 2000).

Furthermore, the act of disregarding OSH is often done by the use of workers/workers without being accompanied by adequate attention and concern to $\mathrm{OSH}$, so that many workers/workers become victims of accidents. Production facilities and infrastructure in the work place (work place) do not meet K3 standards (Hanafi, 2000; Suparman Marzuki, ...; (Mahrus Ali, 2008); Hamzah Hatrik, 1996) the same opinion was stated by Muladi, that the work environment was not healthy and unsafe factors that cause industrial accidents (Etty Utju R. Koesoemahatmadja, 1995). Clinard and Yeager, identified the breach of the corporation's K3 Regulation (M.B. Clinard, and Quinney, 1980; Muhammad Mustofa, 2010) who by Kriesberg as one of the model (Organization process model) of corporate decision-making that violates the law, such as reducing the expenditure to maintain K3 (M.B. Clinard, and Quinney, 1990; I.S. Susanto, 1995). The following is shown the number of cases of industrial accidents and victims died throughout the year 2015 to a semester 2019 sourced from the Data Center and Information Ministry of the Republic of Indonesia. 
Table 1. Industrial Accident Data

\begin{tabular}{|l|l|l|l|}
\hline Number & Year & Number of cases & Fatalities \\
\hline 1. & 2015 & 110.285 & 2.308 \\
\hline 2. & 2016 & 101.367 & 2.382 \\
\hline 3. & 2017 & 123.000 & 3.000 \\
\hline 4. & 2018 & 173.105 & 2.575 \\
\hline 5. & 2019 & 85.100 & \\
\hline
\end{tabular}

Based on the accident data above, the Ministry of Manpower, which is recognized as OSH (K3) standard in Indonesia, is still bad, every day 8 (eight) workers die. The ILO provides information on workplace conditions. The same concern was also conveyed by the Indonesian Labor Institute, Local Initiatives for OSH Network (LION), and the People's Alliance for OHS. The Ministry of Manpower reminded the industry to increase demands for OSH norms and demand commitment to provide legal certainty and enforce the law on OSH implementation. Related to the protest, it is proven that the rampant crime of $\mathrm{K} 3$ worker / labor protection is not followed by law enforcement (Running Text Metro TV, 2014). During 25 years after independence, Indonesia still enforces security regulations (Veiligheids reglement) Stbl. 1910 No. 406 in factories and workplaces until the discharging of UUKK on 12 January 1970. Lawmakers in the general explanation of UUKK suggest that the reason for his/her dismiscidation is called Stbl. 1910 No. 406 to UUKK, which is:

First, since Stbl. 1910 No. 406 enforced has undergone many developments, therefore it is necessary to the development of worker/labor protection and technological advancement. Second, industrialization has increased the intensity of operational work and workplaces. This progress also led to the intensive mobilization of workers. Fatigue, inattention, loss of balance and others are a result and become the cause of "accident". Materials containing toxins, machinery, tools, planes, etc. as well as poor ways of working, lack of skills and work, training, absence of knowledge of new sources of danger become sources of danger and diseases caused by occupational illness. Third, the supervision in Stbl. 1910 No. 406 is entirely repressive, and it is necessary to act with a change of principal, which is directed into a deeper oversight on the preventative nature. Need a good arrangement before the companies are established, because it will be difficult to change or remodel what has been built and installed in it to fulfill the OSH requirements. Fourth, the government wants advanced laws in order to achieve good and realistic security which is a very important factor in providing security, security and comfort to workers. Fifth, UUKK when compared with Stbl. 1910 No.406 has experienced many important changes, both in content and form and systematic. For the reasons above, the UUKK should be a breakthrough in national law in efforts to protect OSH workers/laborers. UUKK should be a breakthrough national law in the protection efforts of OSH workers. It is seen in the content of the considerations UUKK, which is the principal mind that is considered the establishment of UUKK. It is said that every workforce and every other person in the workplace is entitled to the protection of his salvation in doing his job to increase his prosperity. This means, that without prejudice to the large role of corporate economic activity on society and the country, protection of OSH workers must remain the foremost. The maker of the UUKK in his consideration seems 
to mean that the company in carrying out its business activities must be dignified, not contrary to Labor/labor rights in the workplace. Regarding OSH as a human right, the right to safety and health at work is enshrined in Article 23 of the United Nations Universal Declaration of Human Rights, 1948, which states, "Everyone has the right to work, to free choice of employment, to just and favorable conditions of work ....

"And also Article 7 The United Nations International Covenant on Economic, Social and Cultural Rights, 1976, reaffirms this right in the following terms, of just and favorable conditions of work, which ensure, in particular: ... (b) Safe and healthy working conditions ... ".

The state through UUKK provides a guarantee of OSH protection for the realization of the welfare of workers/workers as the nature of national development of Indonesia, the goals and ideals of the Indonesian nation as expressly defined in the paragraph fourth UUDNRI of 1945, which reads, “... Indonesia's country protects all Indonesians and all over Indonesia's blood to advance the general welfare, educates the nation's life... Based on independence, eternal peace, and social justice...

"(Kristian 3, 2014). The opinions of Alvi Syahrin can be expanded, that the law (UUKK) as a rule in the dynamics of society should be able to play its role as a social engineering because it gives basic and also the direction of development to remain in accordance with the insight and The sublime values of the Indonesian personality (Alvi Syahrin, 2009).

During the enforcement of UUKK, every year cases of industrial accidents in Indonesia is quite high. Based on the results of the study, it was difficult to find cases of accidents that were examined until the criminal court level. In the period of the data weaver in the years 2012, 2014, 2015, 2016 and 2017 successfully found ten cases of industrial accidents are examined at the level of the court that has fixed legal force (in Kracht van Gewijsde), namely by the number Article:

1. Court Ruling of Tanjung Pandan No: 93/Pid. B/2013/PN-TDN,

2. Court Ruling of Dumai No. 316/PID. B/2013/PN. DUM,

3. Court Ruling of Klas IB No. 133/PID. B/2014/PN. DUM.,

4. Court Ruling of Batam No. 286/PID. B/2015/PN. BTM,

5. Court Ruling of Rembang No. 52/Pid. Sus/2016/PN/PNRbg,

6. Court Ruling of Sungai Liat No. 609/Pid. B/PN. SGT,

7. Court Ruling of Tuban No. 113/Pid. Sus/2014/PN Tbn,

8. Court Ruling of Klas IA Jambi No. 175/Pid.B/2014/PN.Jbi,

9. Court Ruling of Banten No. 40/PID/2014/PT. BTN, and

10. Court Ruling of Bekasi No.1592/Pid. B/2015/PN Bks.

However, from the tenth case of an indicted accident is not used as the basis for the alleged prosecution and prosecution of criminal offenses. Prosecutors and judges only refer to the code of criminal code and other laws outside of such criminal code. 


\subsection{Significance of the study}

This research is very important, so it can be known the root cause of malfunction and cannot be confirmed UUKK in the effort to counter criminal protection of employees/workers K3. The function of UUKK can mean the failure of criminal policy as part of law enforcement policy, which as a whole is a part of social politics (social policy), namely the efforts of society or country to improve the welfare of the People (Muladi, 1990). As also stated Barda Nawawi Arief, this criminal policy is not separated from the broader policy, which is "social policy" (Social policy), through a policy formulation or efforts for social welfare (social welfare policy). and social defense policy. If the policy of crime prevention (criminal politics) is done using the means of penal (criminal law), then the policy of criminal law (penal policy), especially at the level of judicial policy/applicative (Criminal law enforcement in Concreto) Must observe and lead to the achievement of the objectives of social policy, such as social welfare and Social Defence (Barda Nawawi Arief, 1990). Thus, if a dysfunctional UUKK means an attempt to enrich the worker/labor cannot be realized, because criminal policy through the means of penal to protect K3 workers/workers at the application level does not work. The ultimate goal of the importance of this research is the functionalization of criminal law, i.e. efforts to make UUKK can function, operate or work and materialize concrete. Functionalization occurs if the UUKK can be resolved. If the UUKK is functioning in tackling the work-protection of OSH workers/labors, then the effort to realize the welfare of workers/labor can be realized.

\subsection{Scope and Limitation of the Study}

The scope and limitation of this research is limited to the formulation phase of UUKK, known as legislative policy or formulation policy, namely law enforcement in abstract by the makers of UUKK. Legislative policy is the planning of the UUKK maker on what will be done in the face of certain problems or implementing something that has been planned (Barda Nawawi, unknowns) after Veiligheids reglemen 1910 (Stbl. 1910 No. 406) is considered to be no longer appropriate with the development of worker/labor protection and technology. UUKK maker chooses to use the penal take (penal policy). Thus, the scope and limitation of this research is only to the fundamentals of a criminal law formulation policy (criminal order) in UUKK, consisting of: formulation of criminal act, formulation of criminal responsibility, and formulation of sanction. Formulation policy is the first phase of 3 (three) stages of the functionalization of criminal law. Furthermore the application stage and execution phase (Dwidja Priyatno and Kristian, 2017). Thus, penal policy is one of the most important steps in making criminal law "functional", operating, and working and in real form. Barda Nawawi Arief argues that the formulation stage is the most important stage and plays a big role and is cheerful in the operation of criminal law policy, especially in terms of prevention and countermeasures of criminal acts. Christians, with the same opinion said, the formulation stage will determine which legal product has been made enforceable (enforceable). The fault/weakness of legislative policy is a strategic mistake that can be an obstacle to prevention and countermeasures crimes at the application and execution stage (Sudarto, 2007).

\subsection{Setting of the Study}

This study was conducted in 2017 at the Data and Information Center (Pusdatin) of the Ministry of Manpower Jakarta to obtain data on the number of industrial accidents in 34 provinces and regencies/cities throughout Indonesia. The researchers acquired 5 provinces with the highest 
accident case of the average number of cases in the years 2012, 2014, 2015, 2016 and 2017, namely East Java province, Central Java province, West Java province, Riau province, and Banten province. Then the 5 highest regencies/cities were obtained from each of the five provinces. This study is to find the number of accidents that are up to the court level based on UUKK. Research was continued at the Directorate of Manpower Law Enforcement, to obtain data on the ongoing accident and investigation and prosecution in court. The research will also be recognized at the Directorate of the norm Supervision of the Ministry to add or complete existing data. Further researching in the form of direct interviews with the Director General of development of Employment Supervision and OSH Ministry of Manpower to obtain opinions and understanding of Ministry of Manpower, especially related to UUKK and its application.

\section{Findings And Conclusions}

What is the hope and aim of criminal policy in the UUKK contrary to the statement of Director General of Construction Supervision of manpower and OSH, which said that the nuance of the establishment of UUKK is not detached from the political atmosphere of the nation Indonesia's ongoing development? Therefore, the formulation policy is required to be more coaching and preventive (preventive) than the action (Interview with Maruli A. Hasoloan, 2016). However, UUKK does not regulate the coaching restrictions in question. The UUKK is more likely to act as a consequence of the distribution of the penal line as a rational attempt to cope with the working criminal offense of OSH workers/labors. Furthermore, it can be concluded that it is not functioning and it cannot be declared that UUKK is due to its poor policy formulation rules, so that by law enforcement is difficult to serve as the basis of prosecution and criminal prosecution in matters Industrial accident cases. Likewise, employers/ corporations do not have the burden to commit a criminal offense to protection of workers/labor in conducting its business activities. The results of the study of the formulation policy of the criminal rules in UUKK, found some weaknesses so that the UUKK dysfunctional and non-enforcement, namely:

\subsection{The formulation of Criminal Act}

Consisting of two elements namely; first, the formulation of terms is intended as the subject of criminal law within. The term intended as a subject of criminal offence is of paramount importance, as it is closely related to criminal liability or the parties to which the criminal liability is requested. The terms used by UUKK are "entrepreneurs" and "managers". Employees supervisory and OSH officers both central and regional as authorities in the construction and supervision of OSH, "entrepreneurs" and "managers" are only accepted to the subject of individual law (Natuurlijk persoon). In fact, by interpretation of a systematic method then based on the opinion of jurists, and the law of companies "entrepreneurs" and "caretakers" also intended the subject of law "corporations (Rechts persoon)". Remmelink (Alvi Syahrin and Fadlielah Hasanah, 2014) says, in the practice referred to by the caretaker are those "who give orders" or "the lead". The sense given by Remmelink is used in a number of laws outside the criminal code, for example in use in section 116 paragraph (2) of Law No. 32 of 2009 on Protection and Environmental Management (UUPPLH), just do not Using the term "caretaker". Although in Article 1 Item 3 UUKK J, Article 1 Item 5 Act No. 13 of 2003 entrepreneurs are interpreted as persons, individuals of federal or legal entities, but in practice as described above is still an individual person. The law firm's office in an interview is quite difficult to distinguish 
between "businessman" and "manager". "Entrepreneurs" are always identified with "company leaders". In fact, according to Abdulkadir Muhammad in his book "Indonesian Company Law", the businessman as the company's leader only if the entrepreneur runs the company with the help of workers. So, here have two functions, namely as "entrepreneur" and "company leader", and this is in the form of individual corporate law (Abdulkadir Muhammad, 2010). Furthermore, if "entrepreneur" is not running alone or does not participate in running the company, but to have others run the company with power on behalf of the Authored, then the recipient of power (company manager) is referred to as The Company's leadership, which receives power from the businessman as a power giver that similar to the term "caretaker".Article 1 point 2 UUKK gives the meaning of "caretaker" is "the person who has the assignment directly leads a place of work or its own part". UUKK does not explain who is a "caretaker" in an organization/corporation. If referring to Law No. 40 of 2007 of the limited liability company is clearly mentioned, that referred by the caretaker is the 'Board of Directors' appointed in the shareholder meeting (GMS). Resulting of interviews with a number of employment and OSH supervisory officers, not on the uniformity of who is a manager in a company. Thus, it will be difficult to answer OSH criminal protection worker/labor is also the term used as the subject of ambiguous law. Although "managers" and "entrepreneurs" are understood only as Natuurlijk Persoon, but still use the criminal code and other laws as the basis for the indictment, prosecution, and rationale, and five of the cases above only targeting the (worker/field workers) who are considered criminal acts of the "caretaker" and "businessman". Therefore, it is not surprising if the corporation has committed criminal protection of OSH workers because the corporation can enjoy the benefits gained from the results of its efforts and washing hands on various cases of workplace accidents that befall workers/labor. Back to the terms "caretaker" and "entrepreneur" are also intended as the subject of corporate law. This can be known from a number of legislation which becomes the implementation of the UUKK articles, as in Article 15 paragraph (1) of UUKK. The formulation of the term "caretaker" and "entrepreneur" in UUKK contains meaning that the corporation is also as a criminal offense maker that can be accounted for.

\subsection{The Formulation of Criminal Works}

UUKK contains only a few articles of delict and that can be sentenced. While the formulation of criminal action regarding condition and the requirements of OSH are not found in the UUKK, but spread instead of the implementation of UUKK. Such formulations are certainly also ambiguous for law enforcement in the application stage. According to Act 12 of 2011 on the establishment of legislation, delict and sanctions exist only in the laws and regulations of the region. Once done interpretation assisted by expert opinion, and company law, then in UUKK besides the subject of individual law (Natuurlijk Persoon) can also be interpreted that the corporation is also a criminal act that can be accounted for. But with the discontinuity of the criminal liability model in UUKK, it is difficult to be a guideline for law enforcement, and 3) the formulation of sanctions (sanction). Article 15 paragraph (2) UUKK reads, "The rule of law in paragraph (1) can give criminal threat to the breach of regulation with the punishment of confinement forever 3 (three) months or fines highest Rp.100, 000,-(One hundred thousand Rupiah) "and subsection (3)," the criminal offence is a breach". If the sanction is observed above, it can be concluded that the UUKK stipulates the penal policy as an effort to counteract OSH protection in the workplace. The delict formulated in UUKK is the commission act (Eddy O.S. Hiariej, 2016; Mahrus Ali, 2012) and qualified as a criminal offence (overtredingen) threatened by criminal, i.e. confinement or an alternative fine. The formulation of criminal 
sanctions is formulated in a single, meaning it does not include alternative sanctions other than criminal sanctions. In other words, UUKK chooses premium remedium facilities However, with such mild sanctions it will not be used to fulfill the purpose of penal policy. If these consistent preventive properties are retained, then lawmakers also apply the ultimum remedium at least for certain delicts, as well as formulate some alternative sanctions other than criminal sanctions.

\section{Recommendations}

In order for the UUKK to be enabled, operate and be realized in a concrete effort to counteract the protection of OSH workers/labors, it must be returned to criminal law politics (Strafrecht Politiek) or political or criminal policy (criminal policy) to be carried out for legal reform, especially against the fundamentals of the formulation policy of the criminal rules in UUKK, namely:

1) The use of terms that do not cause ambiguous. There are further explanations of "managers" and "entrepreneurs", both intended as Natuurlijk Persoon and Rechts persoon. You should also use the term "corporation" other than the two terms above.

2) UUKK formulates a strict accountability model, especially to the corporation. The corporate criminal liability model should use the model of the Board and the corporation as a manufacturer and both can be held accountable. This Model has been applied well in a number of laws, among others: Act No. 32 year 2009, Act No. 35 of 2009 about Narcotics, Act 31 of 1999 jo. Law 20 of 2001, etc.

3) Formulate criminal sanctions in accordance with criminal developments. In addition to using premium remedium facilities, it is also good to use ultimum remedium facilities with administrative sanctions. The UUKK does not formulate a single sanction but also uses other sanctions besides criminal sanctions, namely sanctions for actions. Criminal sanctions are not only in the criminal subject, but also add additional criminal. Cumulative sanctions are allotment, or at least a cumulative alternative. It is also good to use fines for criminal sanctions of multiples, as used in Veiligheidsreglement 1910 (Stbl. 1910 No. 406). Therefore, a security criminal offence of workers is a violation of basic rights, labor rights/labor in the workplace, then the qualification of criminal offence should be criminal offence (Misdrijven), and although for criminal acts can also be qualified as a criminal offence (Overtredingen).

\section{References}

Soehatman Ramli, 2010). Sistem Manajemen Keselamatan dan Kesehatan Kerja :OHSAS 18001, Jakarta, pp.7.

(Sutan Remy Sjahdeini, 2007). Pertanggungjawaban Pidana Korporasi, Jakarta, pp.1.

(Suma'mur, 1981). Keselamatan Kerja dan Pencegahan Kecelakaan, Jakarta, pp.5.

(Asri Wijayanti, 2010). Hukum Ketenagakerjaan Pasca Reformasi, Jakarta, pp. 9-10.

(Dwidja Priyatno dan Kristian, 2017). Kebijakan Formulasi Sistem Pertanggungjawaban Pidana Korporasi dalam Peraturan Perundang-undangan Khusus di Luar KUHP di Indonesia, Jakarta, pp. vii. 
(Hanafi, 1997). Perkembangan Konsep Pertanggungjawaban Pidana dan Relevansinya bagi Usaha Pembaharuan Hukum Pidana Nasional, Program Pasca Sarjana Universitas Indonesia, Jakarta, pp.7.

(Suparman Marzuki, 1994). Dimensi Kejahatan Korporasi dan Reaksi Sosial, Jurnal Hukum, Vol.1 No.2, pp.10.

(Niall F. Coburn, 2006). Corporate Investigation, Journal of Financial Crime, London, Volume 13, Iss 3 , pp. 348,350 , and 351 .

(H.Setiyono, 2009). Kejahatan Korporasi : Analisis Viktimologis dan Pertanggungjawaban Korporasi dalam Hukum Pidana Indonesia, Malang, pp.63.

(Suparman Marzuki, 1994). pp.14.

(Hanafi, 2000). Kejahatan Korporasi, Fakultas Hukum Universitas Islam Indonesia, Yogyakarta, pp.4.

(Suparman Marzuki, 1994). pp.11-12.

(Mahrus Ali, 2008). Kejahatan Korporasi, Yogyakarta, pp.14-16

(Hamzah Hatrik, 1996). Asas Pertanggungjawaban Korporasi dalam Hukum Pidana Indonesia (Strict Liability dan Vicarious Liability), Jakarta, pp.42-43.

(Etty Utju R.Koesoemahatmadja, 1995). Hukum Korporasi; Penegakan Hukum Terhadap Pelaku Econimic Crimes dan Perlindungan Abuse of Power, Bogor, pp.6.

(M.B. Clinard and Quinney, 1980). Corporate Crime, New York: The Free Press, pp.116.

(Muhammad Mustofa, 2017). Persekongkolan Birokrat-Korporat Sebagai Pola White-Collar Crime di Indonesia, Jakarta, pp.127.

(M.B. Clinard and Quinney, 1980). pp.

116-119.

(I.S. Susanto, 1995). Tinjauan Kriminologis terhadap Kejahatan Ekonomi, Materi Penataran Nasional Hukum Pidana dan Kriminologi, Semarang, pp. 27.

(Running Text Metro TV, 2014). Pelaku Industri Agar Meningkatkan Kepatuhan Terhadap Norma K3. (Kristian, 2014).Hukum Pidana Korporasi Kebijakan Intergral (Intergral Policy) Formulasi

Pertanggungjawaban Pidana di Indonesia, Bandung, pp.1.

(Alvi Syahrin, 2009). Beberapa Masalah Hukum, Medan, pp.9.

(Muladi, 1990).Pertanggungjawaban badan Hukum dalam Pidana, Makalah dalam Ceramah di Universitas Muria Kudus 
(Barda Nawawi Arief, 1990). Fungsionalisasi Hukum Pidana Dalam Menanggulangi Kejahatan Ekonomi, Makalah Seminar Nasional Peranan Hukum Pidana dalam Menunjang Kebijakan Ekonomi, Semarang.

(Barda Nawawi Arief, unknowns). Bunga Rampai Kebijakan Hukum Pidana Perkembangan penyusunan Konsep KUHP Baru, Jakarta, pp.27-28.

(Dwidja Priyatno dan Kristian, 2017). pp. 16.

(Dwidja Priyatno dan Kristian, 2017). pp. vii-viii.

(Sudarto, 2007). Hukum dan Hukum Pidana, Bandung, pp.94.

(Interview With Maruli A. Hasoloan, Jakarta 2016).

(Abdulkadir Muhammad, 2010). Hukum Perusahaan Indonesia, Jakarta, pp.25.

(Abdulkadir Muhammad, 2010). pp.1.

(Eddy O.S. Hiariej, 2016). Prinsip-prinsip Hukum Pidana, Yogyakarta, pp.137-138.

(Mahrus Ali, 2012). Dasar-Dasar Hukum Pidana, Jakarta, pp.102. 